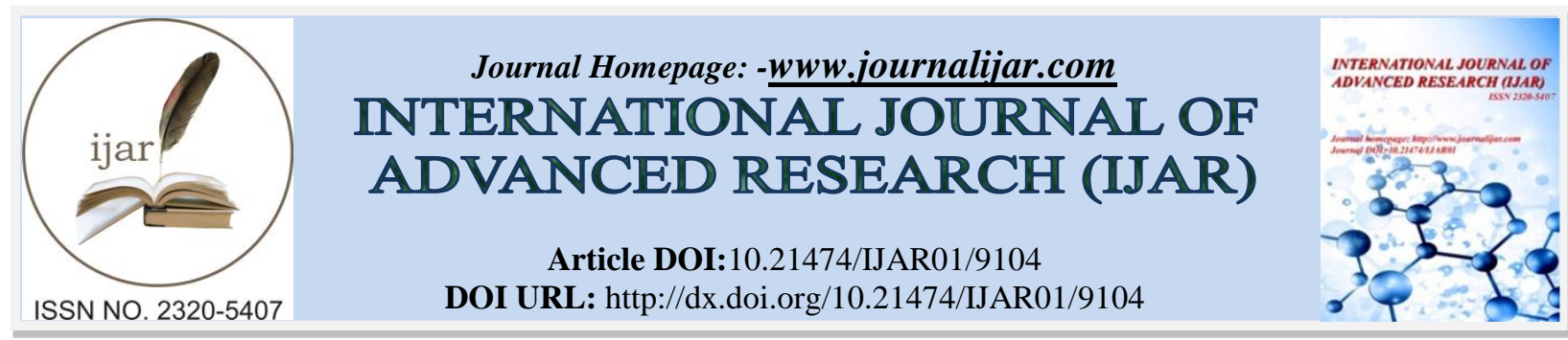

RESEARCH ARTICLE

\title{
THE LEADERSHIP PATTERN STRATEGY OF THE INDONESIAN NAVY (TNI AL) TOWARDS SOLDIERS MOTIVATION IN PEACE MISSION OF THE UNITED STATES (UN)(CASE STUDY OF KRI SULTAN HASANUDDIN-366).
}

\author{
Samsy Subahry Mokoginta ${ }^{1}$, Setyo Widagdo ${ }^{2}$ And Mukhammad Soleh ${ }^{3}$. \\ 1. Postgraduate student of brawijaya university. \\ 2. Postgraduate lecturer of brawijaya university. \\ 3. Postgraduate lecturer of wishnu wardhana university.
}

\section{Manuscript Info}

.........................

Manuscript History

Received: 20 March 2019

Final Accepted: 22 April 2019

Published: May 2019

Key words:-

Leadership, strategy, TNI AL, motivation.

\section{Abstract}

The purposes of this study are 1) analyzing how the motivation of Indonesian Navy soldiers in the KRI Sultan Hasanuddin-366 environment, 2) analyzing the strategy of the leadership patterns of the Indonesian Navy leaders in increasing the motivation of soldiers in the KRI Sultan Hasanuddin-366 environment, and 3) analyzing the model of leadership strategies development at the Sultan Hasanuddin KRI-366 to increase the motivation of TNI AL soldiers. This research was conducted at KRI Sultan Hassanudin-366 in December 2018 to February 2019. This study uses a qualitative descriptive method. The result of this study are motivating Indonesian Navy soldiers in the KRI Sultan Hasanuddin-366 environment the leaders carry out activities, The leadership role of the Indonesian Navy leaders towards the motivation of soldiers in the KRI Sultan Hassanudin-366 environment uses relational leadership with the characteristic, and The model of leadership strategy development at the KRI Sultan Hassanudin-366 to increase the motivation of the Indonesian Navy soldiers with a Transformational leadership.

Copy Right, IJAR, 2019,. All rights reserved.

\section{Introduction:-}

Leadership can be conceptualized as an interaction between a person and a group, especially between a group member and each participant in a role playing role and in certain ways that role must be separated from one another. Basic selection is a matter of influence, leaders influence and others are influenced. Dr. Thomas Gordon "Group Centered Leadership" Away from releasing creative power of groups). Kartini Kartono (1994) Leadership is specific, distinctive, and necessary for a particular situation. Because in a group that does certain activities and has a purpose and special equipment, Group leaders with characteristics are a function of special situations. Therefore through a leadership strategy that is owned by a leader, he can transfer several values such as group emphasis, support from people / employees, tolerance to risk, wage criteria and so on. On the other hand, employees, employees or people led will form a subjective perception of the basics of values that exist within the organization in accordance with the values that the leadership wants to convey through its leadership strategy. Therefore, leadership until now is still seen as a very important factor for organizational effectiveness. Leadership in the military world is still believed to be the best model of leadership in the world (Kristianto Setio Hari Purnomo, 2015).

Corresponding Author:-Samsy s. Mokoginta.

Address:-Postgraduate student of brawijaya university. 
The military organization (in this case) the Republic of Indonesia Warship (KRI) requires the existence of potential human resource factors both superiors, officers and members in the pattern of duties and supervision which is a determinant of achieving basic tasks. Human resources are central figures in the KRI organization, so that management activities run well, KRI must have knowledgeable and highly skilled officers and efforts to manage KRI as optimally as possible so that the motivation of members to work can increase. According to Setiyawan and Waridin (2006) employee work motivation is the result or work performance of employees who are assessed in terms of quality and quantity based on work standards determined by the organization.

Leadership strategy is a behavioral norm used by someone when the person tries to influence the behavior of others (Suranta, 2002). The leadership strategy will be suitable if the company's goals have been communicated and the subordinates have received it. The right leadership strategy will lead to someone's motivation for achievement, the success or failure of employees in work performance can be influenced by the leadership of their superiors (Hardini, 2001 in Suranta, 2002).

\section{Research purposes: -}

Based on the above background, the research objectives are as follows;

1. How is the motivation of Indonesian Navy soldiers in the KRI Sultan Hasanuddin-366 environment?

2. What is the strategy of the leadership patterns of the Indonesian Navy leaders in increasing the motivation of soldiers in the KRI Sultan Hasanuddin-366 environment?

3. How is the model of leadership strategies development at the Sultan Hasanuddin KRI-366 to increase the motivation of TNI AL soldiers?

\section{Research Methods:-}

Types of research:-

This type of research is descriptive qualitative research, because this study describe the findings in the field qualitatively. Qualitative research has a goal to be achieved is in order to understand social phenomena through a holistic picture and multiply deeper understanding (Moleong, 2009).

\section{Data source:-}

The type of data that collected in this study is primary and secondary data. Primary data is obtained through interviews and observations, while secondary data is obtained through research files related to research. Respondents in this study were the Commander of the KRI Sultan Hasanuddin-366 KRI Staff Sultan Hasanuddin366 Officer and several KRI Sultan Hasanuddin-366 Members.

\section{Data analysis:-}

The data analysis that will be used in this study is the analysis of interactive data according to Miles \& Huberman (2014), in the qualitative data analysis activities carried out continuously from the beginning to the end of the study so as to obtain solid data. Analysis of the data has three types of activities in this interactive model, such as data reduction, data presentation, and conclusion drawing.

\section{Location and Time of Research: -}

The location of this research activity was carried out on the KRI Sultan Hassanudin-366 in December 2018 to February 2019.

\section{Research Result And Discussion:-}

Motivation of Indonesian Navy Soldiers in the KRI Sultan Hasanuddin 366: -

Hasibuan (2005) defines motivation as providing a driving force that creates the excitement of one's work, so that they will cooperate, be effective and integrated with all their efforts to achieve satisfaction. In an organization / company environment, there is a tendency for users of intrinsic motivation to be more dominant than extrinsic motivation. This condition is mainly due to the fact that it is not easy to raise awareness of the workers, while the surrounding working conditions lead to more work satisfaction that can only be fulfilled outside of him. In the above conditions, it is necessary to attempt to integrate motivational theories, to be used operationally within the organization. As we know motivation is a process whereby needs encourage a person to carry out a series of activities that lead to the achievement of a particular goal, or can be interpreted as a person's (energy) strength which can lead to persistence and enthusiasm in carrying out an activity, so that motivation can be divided into two main 
parts, namely: (1) Motivation originating from outside a person, known as Extrinsic Motivation, and (2) Motivation originating from within a person, known as Intrinsic Motivation. Motivation is important because motivation causes people to work hard and enthusiastically achieve optimal results.

Firm leadership plays an important role. If people are in a mission operation or on a guardian mission, the mission will be the second nature. In this form, leader leadership is to move followers to surpass themselves as attractive and help improve members.

In an interview with Sea Major (E) Prasetyo Agung Budianto, ST, M.Tr.Hanla conveyed in his interview that "The effect of leadership that has been carried out:" with the existing leadership model, has resulted in the emergence of high morale of the soldiers in carrying out the MTF mission UNIFIL in Lebanon. Furthermore Northouse (2004) also defines good leadership and serves "a strong altruistic ethical tone that emphasizes leaders paying attention to the problems of subordinates; they must be sensitive and pay attention to them, maintain them and instead they will be loyal to the leaders". We need to note that a leader must know and experience individually as a servant then the basics of leadership can be honed during the learning process (Northouse). The strategy to increase the motivation of the KRI Sultan Hasanuddin-366 used was also explained in an interview with Marine First Lieutenant (P) Ardiansyah Putra Ramadhan, S.T.Han, such as:

\section{Plan the work carried out}

Before starting the existing work on board, the first thing to do is to plan activities in advance. With careful planning, the hard work will be easy because there is a step by step activity that has been set. With this planning members who will work understand what things will be done and what things should not be done.

\section{Providing rewards for outstanding members}

The giving of this reward is important as a form of appreciation from the leader to his soldiers who have given their best performance to the organization / ship. We can provide bonuses or incentives that are worth the achievements. In this way it is quite capable of boosting the spirits of other soldiers to make the best achievements for the institution.

Direct the planned work so that it can be carried out well and successfully by giving rewards to subordinates who are able to work well, discipline and excel.

\section{Strengthen the kinship of fellow soldiers}

The close kinship of fellow soldiers will make them feel comfortable at work. Not only that, their loyalty to the institution will also increase. This can be built by the ship by holding a cruise / recreation together when the ship docked / anchored in the city of Beyrut Lebanon, among others; joint travel to the Faraya iceberg, carrying out mini outbound when the ship docked, shared dinner and sports together between each ship's department and scheduled for a dock in the mining city of Turkey. This aims to establish the familiarity of the soldiers in the ship.

\section{Recognize the weaknesses and strengths of each soldier.}

They have their own characteristics. As a leader, you need to recognize the strengths and weaknesses of the soldiers in order to optimize work motivation in the ship. With this approach, it will be able to help soldiers who have difficulty working on their tasks to be able to achieve achievements like other colleagues

Giving training to soldiers regularly and periodically, sometimes when doing the same work every day makes the soldiers in the ship become bored and bored.

Strategies that can be done by giving training to soldiers both in new knowledge will be able to provide motivation to revive their morale while increasing their knowledge and insight, by providing training in lessons that can open insights, such as teaching Computer and English Language for members who do not understand and aim to improve skills in their duties.

It is illustrated that the leadership style that serves will cause authority to shift to those who are being led so that the dynamics of power and control are very important for and become a secondary need to strengthen trusting relationships within the organizational hierarchy (Perry \& Mankin, 2007). 
The Role of Navy Leaders Against the Motivation of KRI Environmental Soldiers Sultan Hassanudin-366: How is the relationship between leadership style and motivation according to Manning and Curtis, "there are two aspects of leadership that must be considered: first, is commitment to the task and the second is equally important, is concern for others". Effective leadership has the potential to inspire subordinates in an organization and this also has implications for increasing productivity. Leaders need to create passion / enthusiasm among subordinates so that they can see meaning and understand in the various roles they lead. Both enthusiasm and inspiration are the main ingredients in motivation. In an interview revealed by the KRI Commander Sultan Hassanudin (Marine Lt. Col. (P) Cecep Hidayat SE, M.Sc.), that "leadership is an ability to lead or influence other people to achieve goals where it is deeply influenced by personality traits such as authority, firmness, discipline, from the leader to convince others he leads to be able to carry out the workload or work sincerely, passionately, happily and not forced ". This opinion illustrates that a leadership style that has a sense of tolerance to share and instill the importance of the organization's vision with other subordinates becomes very important in the process of motivating subordinates. As soon as each language understands the goals and objectives carefully it creates an environment of togetherness from an organization in this context the scope of KRI Sultan Hassanudin as stated in his vision statement, then it will also be much easier for leaders to build motivation in it. Subordinates spontaneously will have a strong desire to achieve the goals of the organization if they understand or include themselves with their vision (Maddock \& Fulton 15). It can be concluded that through a relational leadership style can create a vision that can be accepted effectively both from the top level leadership to the subordinates and juniors.

According to KRI Commander Sultan Hasanuddin-366 there are factors that influence the decline in the motivation of soldiers on a mission that has a long duration:

\section{Saturation Factors}

From day to day the activities carried out by soldiers in the assignment of MTF UNIFIL almost always carry out the same activities, so that it has the potential to increase boredom in every soldier

\section{Family factors}

With the length and duration of the assignments carried out, of course there will be a feeling of homesickness for the families left in the country, this has the potential to affect the decline in motivation of soldiers.

\section{Factors of dissatisfaction with the leadership model}

The occurrence of disagreements between leaders and members they lead is things that can potentially occur in an organization. Not all soldiers can accept the decisions that have been taken by their leaders, so if this happens repeatedly, it can potentially decrease the motivation of the soldier concerned.

However, there are disadvantages when bond leaders are too close to team members. For example, charismatic leaders who seem extraordinary and able to make everything run efficiently, but, at one time failed to delegate the role of being a good leader to members. It can produce bad results in the long run. Such leaders are considered failed to empower team members to direct subordinates to maximum motivation.

\section{Leadership Strategy Development Model at KRI Sultan Hassanudin-366: -}

The right leadership strategy model and from the results of primary and secondary data analysis, this study found that the model that was very suitable in the leadership of KRI Sultan Hassanduin-366 was the Transformational leadership model. This theory also seeks that subordinates have an understanding of a clear mission that their leaders try to convey to followers of members. Furthermore, this proves that such leaders also tend to have superior debating skills, technical expertise and persuasive skills ". The transformational leadership theory platform is made from "4I's" (Bass \& Riggio, 2006).

The benefits of transformational leadership theory:

1. Individual Support: Transformational leaders tend to encourage and provide support to individuals to subordinates to achieve their targets.

2. Motivation for Inspiration: Transformational leaders have a clear vision that they want to convey to their subordinates to help achieve the target.

3. Charismatic. leaders behave pleasantly, show confidence and take a position that can cause subordinates to identify a task and mission together with leaders who have and also have a clear set of values and act as role models for members. 
Factors that lead to military leaders become great According to Colonel Kolditz, there are three main factors that influence the military to produce great leaders; training, organizational strength, and individual sacrifice. Charam (2007) suggested six personal traits that could influence military leaders to become excellent leaders; ambition, encouragement and tenacity, self-confidence, psychological openness, realism, and learning ability.

The following is a draft strategy for overcoming inhibiting factors, such as:

\section{Exercise}

Training is progressive, step by step involving experiments in practicing real situations during war or in very difficult situations. All of this, aims to form a soldier through training to be mentally and physically strong so that they are ready to face every challenge in the task.

\section{Organizing Ability}

Junior officers in the army, for example, are given very high abilities in terms of organizational structure proportionally and also with assignments given. They are prepared in progress, the strength of which must increase gradually; something that makes them confident and emotionally motivated to carry out their duties perfectly.

\section{Self-sacrifice}

Military leaders and their members are built on "the concept of independent duty, service and sacrifice" And this is supported by the oath they take when they are assigned, that they will always put their common interests and goals above their own interests.

Important spirit factor to influence the motivation of fighting and this is an institutional system manifested by military organizations; the values most relevant to the members of the unit are very important. In the case of the Indonesian Navy: "(1) Persistence is the goal of carrying out missions and encouraging success; (2) Responsibility; (3) Credibility; (4) Personal Will; (5) Reflection of Life; (6) Weapon Use Skills; (7) Professionalism; (8) Discipline;

(9) Comrade ship; and (10) Sense of Mission ".

\section{Conclusions And Suggestions:-}

\section{Conclusions: -}

In motivating Indonesian Navy soldiers in the KRI Sultan Hasanuddin-366 environment the leaders carry out activities including:

1. Plan the work to be carried out

2. Providing rewards for outstanding members

3. Strengthening the kinship of fellow soldiers (Corsican soul)

4. Recognize the weaknesses and strengths of each soldier to develop

5. Providing regular and periodic training for soldiers to improve the skills and performance of soldiers.

The leadership role of the Indonesian Navy leaders towards the motivation of soldiers in the KRI Sultan Hassanudin-366 environment uses relational leadership with the characteristic that a leader is far more than just a manager who explains the principles that must be followed by subordinates. In addition, a KRI leader Sultan Hasanuddin-366 also sought to build a team through coordination within the organization. Leadership is not only about showing the way but also leading the way. From this understanding, a very strong relationship was built between leadership and motivation within the scope of KRI Sultan Hasanuddin-366.

The model of leadership strategy development at the KRI Sultan Hassanudin-366 to increase the motivation of the Indonesian Navy soldiers with a Transformational leadership approach which will form leaders with good leadership in the realm of military leadership or elsewhere, especially transformational leaders will always reflect themselves and always reflect in order to feel what is being experienced naturally. Furthermore this will create a bond with the help of their leaders, the subordinates can change for the better and towards completing the mission in front of them.

\section{Suggestion: -}

1. For academics, in further research, we hope to examine more deeply the style of military leadership in the civilian realm.

2. For the Government, hope to establish a leadership study institute for the formation of a mental generation that has a good lead orientation. 
3. For related institutions, presumably research on the new leadership model must continue to be rigorous to add to the leadership model that fits the actual situation and conditions.

\section{Bibliography:-}

1. Bass, M. Bernard Dan Riggio, E. Ronald. 2006. Transformational Leadership.Second Edition. New Jersey: Lawrence Erlbaum Associates, Inc.

2. Hasibuan. 2005. Pengeruh motivasi dalam menggerakan seseorang. Hal 95.

3. Huberman, \& Miles. 2014. Analisis data dalam melaksnakan penelitian. Hal 16-20.

4. Kartini, Kartono. 1994. Pemimpin Dan Kepemimpinan, Jakarta: Pt. Rajawali Grafindo Persada. Hal:48.

5. Moleong, L. 2009. Metode Penelitian Kualitiatif. Bandung: Rosdakarya. Hal 14-21.

6. Northouse. 2004. Leadership : Theory And Practice. Https://Www.Worldcat.Org/Title/Leadership-Theory-And Practice/ Oclc/51290329.

7. Purnomo, Kristianto. 2015. Model Kepemimpinan Pada Organisasi Militer Perspektif Transformasional. Hal:24.

8. Setiyawan, Budidan Waridin. 2006. Pengaruh Disiplin Kerja Karyawan Dan Budaya Organisasi Terhadap Kinerja Di Divisi Radiologi Rsup Dokter Kariadi Semarang. Jrbi. Vol2. No2. Hal:181-198.

9. Suranta, Sri. 2002. Dampak Motivasi Karyawan Pada Hubungan Antara Gaya Kepemimpinan Dengan Kinerja Karyawan Perusahaan bisnis. Empirika. Vol15.No2. Hal:116-138. 